\title{
KERAGAAN PENYAKIT BAKTERIAL IKAN NILA (Oreochromis niloticus) PADA KERAMBA JARING APUNG (KJA) DI LOKASI BERBEDA
}

\author{
Hambali Supriyadi', Ani Widiyati"), Agus Sunarto"), dan Tri Heru Prihadi")
}

\begin{abstract}
ABSTRAK
Penelitian ini bertujuan untuk mengetahui keragaan penyakit terutama penyakit ikan bakterial pada sistem budi daya Keramba Jaring Apung (KJA) di Waduk Cirata dan Gadjah Mungkur pada musim penghujan dan kemarau. Ikan sampel berupa ikan nila (Oreochromis niloticus) diambil sampling sebanyak 40 ekor per lokasi sampling. Di mana tiap waduk ditentukan 4 (empat) lokasi sampling. Isolat diambil dari ginjal dan cairan otak dan ditanamkan pada media Tryptic Soy Agar (TSA) dan Brain Heart Infusion Agar (BHIA). Identifikasi bakteri dilakukan dengan penelusuran bentuk, sifak fisik, dan biokimia. Kualitas air dan jumlah pakan yang digunakan pada tiap lokasi sampling dicatat dan dianalisis. Hasil penelitian menunjukkan bahwa keragaan bakteri patogen didominasi oleh jenis-jenis Aeromonas hydrophila, Pseudomonas sp., Alteromonas shigelloides, dan Streptococcus sp. Ada kecenderungan bahwa pemanfaatan waduk yang lebih intensif memiliki jumlah dan jenis bakteri yang lebih bervariasi. Keadaan yang sama terjadi akibat pengaruh musim kemarau.
\end{abstract}

ABSTRACT: The prevalence of bacterial fish diseases in floating net cages in Cirata and
Gadjah Mungkur reservoirs monitored in different seasons. By: Hambali
Supriyadi, Ani Widiyati, Agus Sunarto, and Tri Heru Prihadi

The aim of this study is to know the prevalence of bacterial diseases in floating net cages in Cirata and Gadjah Mungkur reservoirs monitored in different seasons. Fish sample is nile tilapia (Oreochromis niloticus) collected from four different locations in each reservoirs. The number of samples as much as 40 fish were taken from each location. Isolates were taken from kidney and brain, isolated onto Tryptic Soy Agar (TSA) and Brain Heart Infusion Agar (BHIA) respectively. Identification of bacteria was conducted based on the morphological, physiological, and biochemical characters. Water qualities were analyzed meanwhile the total number of feed given in each locations were also recorded. The results indicated that pathogenic bacteria are dominated by Aeromonas hydrophila, Pseudomonas sp., Alteromonas shigelloides, and Streptococcus $s p$. It was noted that the more intensive reservoirs is operated, the more variations of pathogenic bacteria are isolated. The effect of seasonal also indicated that more variations of pathogenic bacteria encountered during dry season.

KEYWORDS: prevalence, bacterial diseases, reservoirs, season,floating net cages, Cirata, Gadjah Mungkur

\section{PENDAHULUAN}

Degradasi lingkungan lahan budi daya akibat tingginya cemaran, dan kesalahan pengelolaan budi daya merupakan satu di antara faktor penyebab timbulnya masalah penyakit pada usaha budi daya ikan. Penyakit ikan merupakan salah satu masalah yang perlu mendapat perhatian yang serius pada usaha budi daya ikan. Kerugian yang diderita akibat wabah penyakit ini biasanya cukup besar. Selain kematian ikan, kerugian yang lain adalah berupa penurunan kualitas ikan. Hal ini tentu saja akan berdampak pada harga jual ikan menjadi rendah. Penyakit bakterial misalnya seringkali menimbulkan kerugian yang tidak sedikit bagi para pembudi daya ikan karena penyakit tersebut dapat mengakibatkan kematian sekitar $50 \%-100 \%$ (Supriyadi \& Taufik, 1981; Taufik, 1992; Supriyadi \& Rukyani, 1990). Selain itu, dampak dari infeksi penyakit bakterial dapat menurunkan mutu daging ikan yang terinfeksi berupa borok atau luka, sehingga tidak disenangi oleh konsumen. Penelitian yang telah dilakukan pada tahun 1991/1992 terbukti bahwa ikan nila dapat terinfeksi oleh bakteri Aeromonas hidrophyla dan Enterobacter

Peneliti pada Balai Riset Perikanan Budidaya Air Tawar, Bogor

Peneliti pada Pusat Riset Perikanan Budidaya, Jakarta 
sp. (Supriyadi, 1992). Demikian pula penelitian pada tahun 2002 menunjukkan bahwa ikan nila sangat rentan terhadap infeksi penyakit bakterial antara lain akibat infeksi bakteri Streptoccoccus inae. Prevalensi tertinggi dari infeksi streptococciasis terdapat di Jawa Barat dan Jawa Tengah. Sedangkan penyebaran dari penyakit ini telah meliputi: Jawa Barat, Banten, Jawa Tengah, dan Yogyakarta. Adapun level infeksinya bervariasi tergantung pada tingkatan budi dayanya. Penyakit ini di luar negeri telah banyak mengakibatkan kerugian berupa kematian baik pada ikan nila benih maupun pada ikan nila ukuran konsumsi. Kematian yang diakibatkan oleh penyakit tersebut dapat mencapai lebih dari $75 \%$ populasi (Perera et al., 1994).

Kalau dilihat dari pola atau tingkatan budi daya, ada kecenderungan bahwa semakin intensif budi daya ikan nila semakin tinggi prevalensi infeksi penyakit. Seperti terlihat pada prevalensi infeksi streptococciasis, di mana pada pola budi daya intensif ternyata cukup tinggi. Faktor lain yang merupakan pemicu timbulnya penyakit pada ikan adalah makin menurunnya kualitas air, akibat bahan cemaran berupa limbah industri yang banyak dibuang ke perairan umum tanpa melalui pengolahan terlebih dahulu. Pencemaran dapat juga diakibatkan dari kesalahan manajemen budi daya. Pada pola budi daya intensif, pakan biasanya diberikan cukup banyak, sehingga hasil sisa metabolisme dan pembusukan sisa pakan yang jatuh ke perairan tempat budi daya tersebut dapat menimbulkan cemaran.

Usaha penanggulangan terhadap beberapa penyakit telah banyak dilaksanakan. Penggunaan bahan kimia dan antibiotika yang terus menerus selain dapat mengakibatkan pencemaran lingkungan juga dikhawatirkan dapat menimbulkan akibat lain yaitu timbulnya patogen yang tahan terhadap obat tersebut.

Untuk itu diperlukan suatu cara penanggulangan penyakit yang tidak banyak menimbulkan efek negatif bagi lingkungan. Salah satu cara penanggulangan diharapkan dapat diperoleh melalui suatu model pengelolaan budi daya nila secara terpadu dan komprehensif tercakup di dalamnya pengelolaan pakan, pengendalian penyakit, manajemen budi daya, dan pengelolaan limbah.

\section{BAHANN DAN METODE}

Sampel ikan terdiri atas ikan nila (Oreochromis niloticus) yang dikoleksi dari usaha budi daya ikan nila di KJA pada beberapa lokasi yaitu di Waduk Cirata dan Gajah Mungkur. Sampel tiap lokasi (waduk) diambil dari 4 unit KJA (Gambar 1 dan 2), dan dari tiap unit diambil sampel sebanyak 40 ekor ikan

Isolat diambil dari cairan otak dan ginjal ikan. Isolat dari cairan otak ditanamkan pada media Brain Heart
Infussion Agar (BHIA), sedangkan isolat dari ginjal ditanamkan pada media Tryptic Soy Agar (TSA), kemudian diinkubasikan dalam inkubator pada suhu $28^{\circ} \mathrm{C}$ selama 24 jam.

Identifikasi dilakukan dengan menggunakan metode identifikasi konvensional berdasarkan pada karakter morfologi, fisik, dan biokimia sesuai dengan metode yang dikemukakan oleh Amos (1985); Cowan (1985); serta Frerichs \& Millar (1993).

Derajat insidensi (DI) atau prevalensi penyakit tersebut pada masing-masing grup ikan sampel yang diambil dari berbagai daerah pengambilan sampel dihitung dengan rumus

$$
D I=\frac{\text { Jumlah ikan yang terinfeksi }}{\text { Jumlah sampel yang diperiksa }}
$$

Data tentang pola pengelolaan budi daya termasuk cara dan jumlah pemberian pakan dicatat, demikian juga kualitas air yang ada pada masingmasing lokasi unit pemeliharaan dianalisis. Frekuensi pengambilan sampel dilakukan sebanyak dua kali yaitu pada musim kemarau dan musim hujan.

\section{HASIL DAN BAHASAN}

Keragaan mikroorganisme penyebab penyakit bakterial yang dapat diisolasi dari sampel yang diperoleh dari 2 (dua) lokasi waduk yaitu Cirata dan Gadjah Miungkur serta dikoleksi dalam 2 (dua) musim yaitu musim penghujan dan musim kemarau dapat dilihat pada Tabel 1 dan 2. Bakteri-bakteri tersebut didominasi oleh: Aeromonas hydrophila, Pseudomonas sp., Alteromonas shigelloides, dan Streptococcus sp.

Secara deskriptif nampak acianya kecenderungan bahwa pada musim kemarau bakteri-bakteri penyebab penyakit lebih bervariasi apabila dibandingkan dengan musim penghujan Hal ini terlihat dari data yang diperoleh dari Waduk Cirata dan Gadjah Mungkur (Gambar 3). Hal ini akibat dari perubahan-perubahan kualitas air, di mana pada umumnya kualitas air pada musim kemarau relatif lebih jelek atau menurun apabila dibandingkan dengan musim penghujan. Selain itu, juga ada perbedacin jumlah bakteri pada kedua waduk tersebut. Jumlah bakteri di Waduk Cirata lebih bervariasi apabila dibanding dengan Waduk Gadjah Mungkur. Keadaan ini juga mungkin ada kaitannya dengan jumlah KJA pada suatu luasan, di mana pola usaha di Waduk Cirata lebih padat apabila dibanding dengan Waduk Gadjah Mungkur.

Pada musim penghujan di Waduk Cirata terjadi perbedaan jumlah patogen yang dapat diisolasi. Di Jangari (Cirata 4) misalnya, jumlah bakteri patogen 


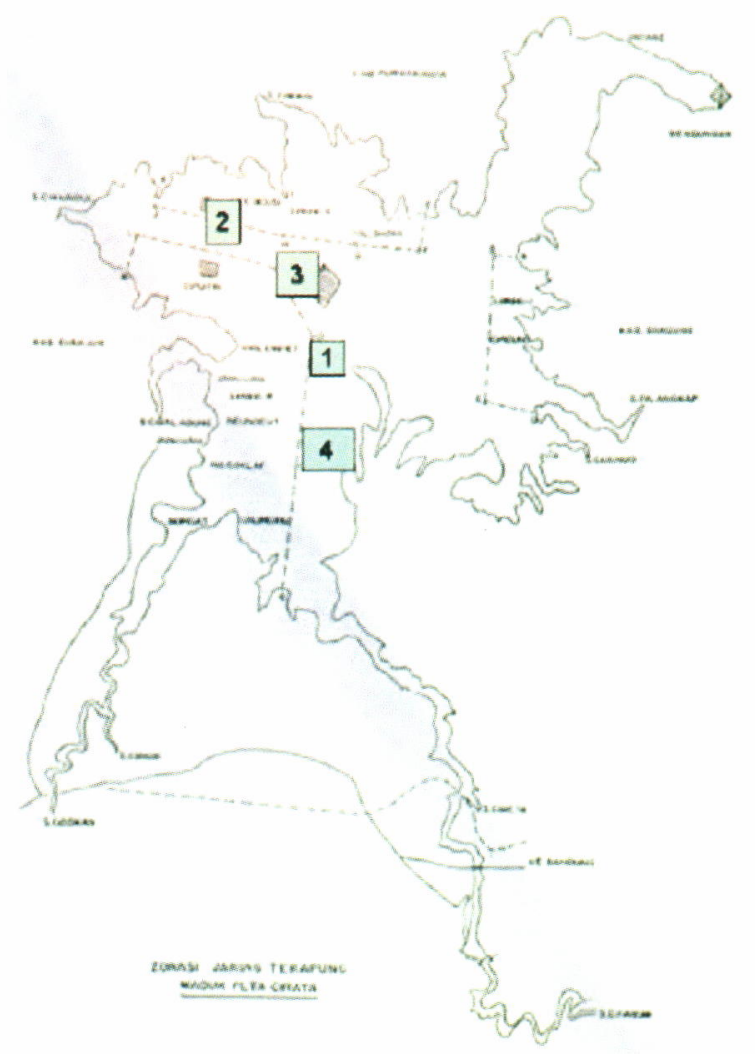

Gambar 1. Peta lokasi Waduk Cirata stasiun pengambilan sampel ikan

Figure 1. Map of Cirata reservoir of sampling station

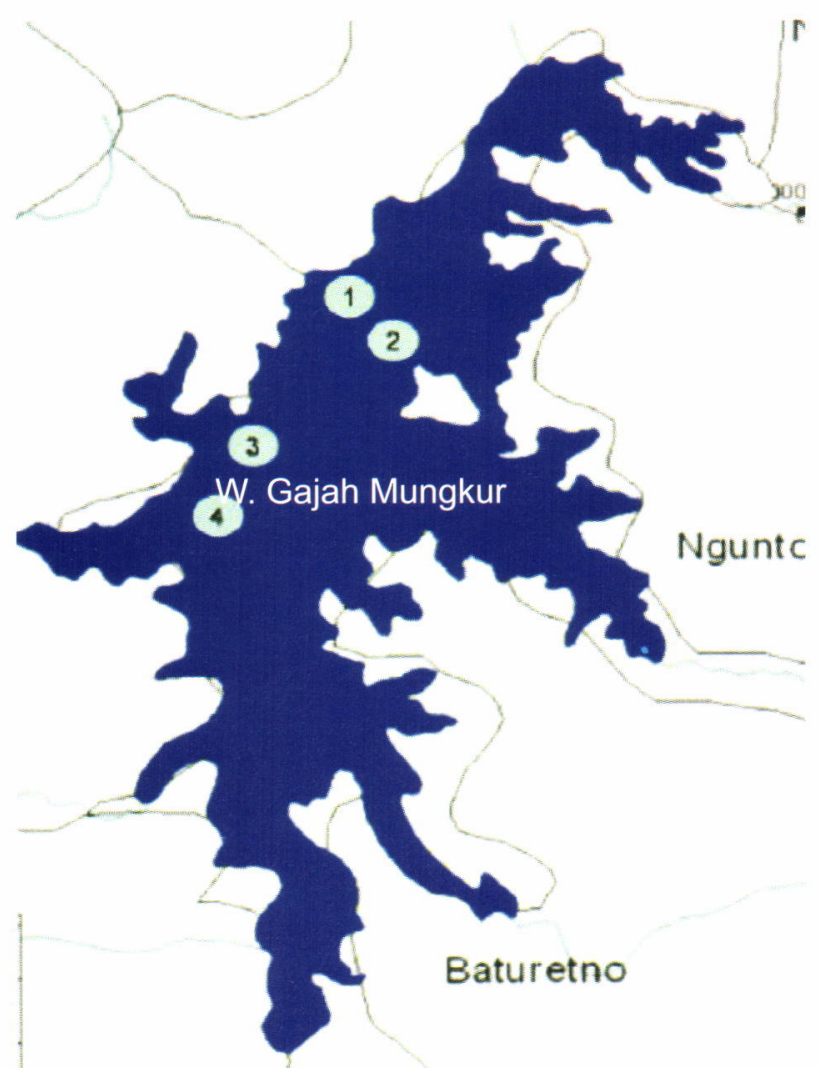

Gambar 2. Peta lokasi Waduk Gadjah Mungkur stasiun pengambilan sampel ikan Map of Cirata reservoir of sampling station

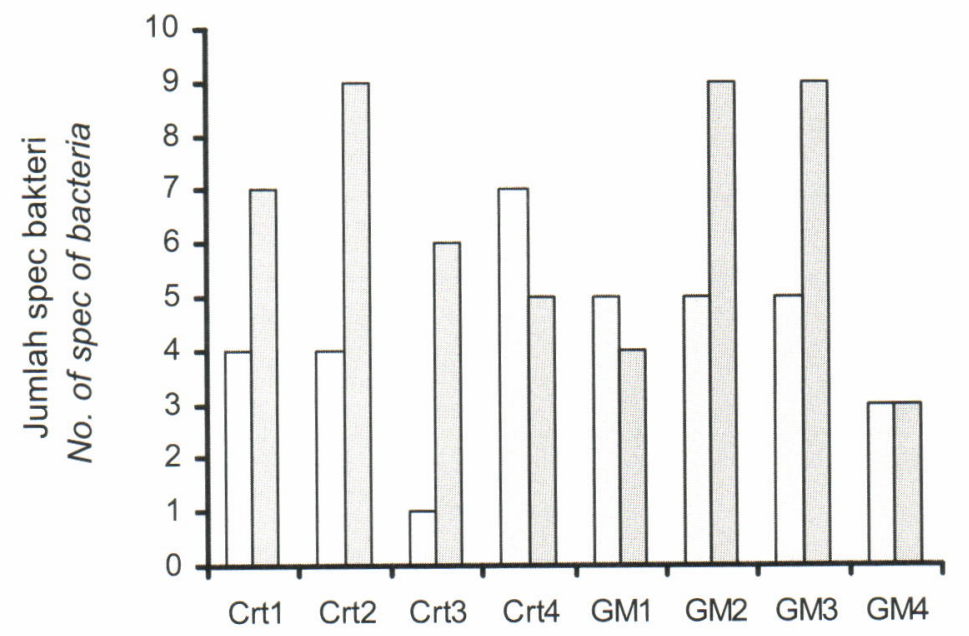

Jumlah spec bakteri (No. of spec of bacteria) Musim hujan (Wet season )

Jumlah spec bakteri (No. of spec of bacteria) Musim kemarau (Dry season)

Lokasi (Location)

Gambar 3. Jumlah spesies bakteri di Waduk Cirata dan Gadjah Mungkur pada musim yang berbeda. (Crt= Cirata, $\mathrm{GM}=$ Gadjah Mungkur)

Figure 3. Number of species bacteria at Cirata and Gadjah Mungkur reservoirs monitored in dry and wet season ( $\mathrm{Crt}=$ Cirata, $\mathrm{GM}=$ Gadjah Mungkur) 
Tabel 1. Jenis dan prevalensi bakteri yang diisolasi dari beberapa lokasi di Waduk Cirata dan Gadjah Mungkur pada musim penghujan

Table 1. Species of bacteria and its prevalence isolated from different location, in Cirata and Gadjah Mungkur reservoirs collected during rainy season

\begin{tabular}{|c|c|c|c|c|}
\hline $\begin{array}{l}\text { Lokasi } \\
\text { Location }\end{array}$ & $\begin{array}{l}\text { Total pakan } \\
\text { Total feed (kg) }\end{array}$ & $\begin{array}{l}\text { Jumlah petak } \\
\text { No. of cages }\end{array}$ & $\begin{array}{c}\text { Jenis bakteri } \\
\text { Species of bacteria }\end{array}$ & $\begin{array}{l}\text { Prevalensi } \\
\text { Prevalence }\end{array}$ \\
\hline \multirow{4}{*}{ Cirata 1 (Nyalempet) } & 144.000 & 64 & Aeromonas hydrophila & 5.0 \\
\hline & & & Pseudomonas sp. & 5.0 \\
\hline & & & Alteromonas shigelloides & 2.5 \\
\hline & & & Streptococcus faecalis & 2.5 \\
\hline \multirow[t]{4}{*}{ Cirata 2 (Cikjdang) } & 82.500 & 22 & Aeromonas hydrophila & 2.5 \\
\hline & & & Alteromonas shigelloides & 2.5 \\
\hline & & & Streptococcus iniae & 2.5 \\
\hline & & & Stretococcus faecalis & 5.0 \\
\hline Cirata3 (Jatinenggang) & 14.400 & 24 & Alteromonas shigelloides & 2.5 \\
\hline \multirow[t]{7}{*}{ Cirata 4 (Janggari) } & 20.000 & 8 & Aeromonas hydrophila & 17.5 \\
\hline & & & Pseudomonas sp. & 2.5 \\
\hline & & & Ateromonas shigelloides & 5.0 \\
\hline & & & Staphylococcus sp. & 25.0 \\
\hline & & & Streptococcus iniae & 7.5 \\
\hline & & & S. faecalis & 7.5 \\
\hline & & & S. agalactiae & 2.5 \\
\hline \multirow[t]{5}{*}{ Gadjah Mingkur 1 (Cakaran 1) } & 2.016 .000 & 240 & Aeromonas hydrophila & 10.0 \\
\hline & & & Pseudomonas sp. & 2.5 \\
\hline & & & Alteromonas shigelloides & 2.5 \\
\hline & & & Streptococcus iniae & 7.5 \\
\hline & & & S. faecalis & 10.0 \\
\hline \multirow[t]{5}{*}{ Gadjah Mungkur 2 (Cakaran 2) } & 2.250 & 6 & Aeromonas hydrophila & 17.5 \\
\hline & & & Pseudomonas sp. & 5.0 \\
\hline & & & Alteromonas shigelloides & 7.5 \\
\hline & & & S. iniae & 5.0 \\
\hline & & & S. faecalis & 12.5 \\
\hline \multirow[t]{5}{*}{ Gadjah Mungkur 3 (Kedungjati 3) } & 5.760 & 6 & Aeromonas hydrophila & 2.5 \\
\hline & & & Pseudomonas sp. & 2.5 \\
\hline & & & Alteromonas shigelloides & 7.5 \\
\hline & & & S. iniae & 10.0 \\
\hline & & & S. faecalis & 7.5 \\
\hline \multirow[t]{3}{*}{ Gadjah Mungkur 4 (Kedungjati 2) } & 6.300 & 6 & Aeromonas hydrophila & 5.0 \\
\hline & & & Psedomonas sp. & 2.5 \\
\hline & & & Alteromonas shigelloides & 7.5 \\
\hline
\end{tabular}

lebih bervariasi ( 7 spesies) apabila dibandingkan dengan lokasi lainnya. Sedangkan pada lokasi lain Jatinenggang (Cirata 3 ) sebaliknya jumlah bakteri patogen paling sedikit.

Kalau dilihat dari kualitas air terutama amonia di Jangari, Cirata 4 (Lampiran 1) ternyata lebih tinggi
$(0,056 \mathrm{mg} / \mathrm{L})$ apabila dibandingkan dengan lokasi lainnya. Walaupun kandungan tersebut masih dalam batas yang tidak toksik bagi ikan, namun dapat menimbulkan masalah bagi kesehatan ikan.

Seperti dikatakan oleh Andrews et al. (1988), bahwa level maksimum amonia yang tidak 
Tabel 2. Jenis bakteri dan prevalensi yang dapat diisolasi dari berbagai tempat di Waduk Cirata dan Gadjah Mungkur pada musim kemarau

Table 2. Species of bacteria and its prevalence isolated from different location in Cirata and Gadjah Mungkur reservoirs collected during dry season

\begin{tabular}{|c|c|c|c|c|}
\hline $\begin{array}{l}\text { Lokasi } \\
\text { Location }\end{array}$ & $\begin{array}{l}\text { Total pakan } \\
\text { Total feed }(\mathbf{k g})\end{array}$ & $\begin{array}{l}\text { Jml petak } \\
\text { Total cages }\end{array}$ & $\begin{array}{c}\text { Jenis bakteri } \\
\text { Species of bacteria }\end{array}$ & $\begin{array}{l}\text { Prevalensi } \\
\text { Prevalence (\%) }\end{array}$ \\
\hline Cirarta 1 (Nyalempet) & 144.000 & 64 & $\begin{array}{l}\text { Aeromonas hydrophila } \\
\text { Pseudomonas sp. } \\
\text { Alteroromonas } \\
\text { Cytrobacter sp. } \\
\text { Escheherichia sp. } \\
\text { Streptococcus iniae } \\
\text { Streptococcus faecalis }\end{array}$ & $\begin{array}{r}5.0 \\
10.0 \\
7.5 \\
2.5 \\
2.5 \\
7.5 \\
2.5\end{array}$ \\
\hline Cirata 2 (Cikidang) & 66.000 & 22 & $\begin{array}{l}\text { Aeromonas hydrophila } \\
\text { Pseudomonas sp. } \\
\text { Cytrobacter sp. } \\
\text { Escherichia sp. } \\
\text { Serratia sp. } \\
\text { Streptococcus iniae } \\
\text { Streptococcus faecalis } \\
\text { Streptococcus agalactiae } \\
\text { Staphylococcus sp. }\end{array}$ & $\begin{array}{r}2.5 \\
5.0 \\
7.5 \\
7.5 \\
12.5 \\
7.5 \\
7.5 \\
15.0 \\
10.0 \\
5.0\end{array}$ \\
\hline Cirata 3 & 14.400 & 24 & $\begin{array}{l}\text { Pseudomonas sp. } \\
\text { Alteromonas shigelloides } \\
\text { Enterobacter sp. } \\
\text { Streptococcus iniae } \\
\text { Streptococcus faecalis } \\
\text { Streptococcus agalactiae }\end{array}$ & $\begin{array}{r}5.0 \\
22.5 \\
7.5 \\
5.0 \\
10.0 \\
2.5 \\
\end{array}$ \\
\hline Cirata 4 (Jangari) & 14.200 & 8 & $\begin{array}{l}\text { Aeromonas hydrophila } \\
\text { Pseudomonas sp. } \\
\text { Enterobacter sp. } \\
\text { Streptococcus iniae } \\
\text { S. agalactiae }\end{array}$ & $\begin{array}{r}5.0 \\
15.0 \\
7.5 \\
5.0 \\
7.5\end{array}$ \\
\hline $\begin{array}{l}\text { Gadjah Mungkur } 1 \\
\text { (Cakaran 1) }\end{array}$ & 2.016 .000 & 240 & $\begin{array}{l}\text { Aeromonas hydrophila } \\
\text { Plavobacterium sp. } \\
\text { Haemophilus sp. } \\
\text { Streptococcus faecalis }\end{array}$ & $\begin{array}{r}2.5 \\
12.5 \\
15.0 \\
2.5 \\
\end{array}$ \\
\hline $\begin{array}{l}\text { Gadjah Mungkur } 2 \\
\text { (Cakaran 2) }\end{array}$ & 2.250 & 6 & $\begin{array}{l}\text { Aeromonas hydrophila } \\
\text { Pseudomonas sp. } \\
\text { Cytrobacter sp. } \\
\text { Achromobacter sp. } \\
\text { Haemophilus sp. } \\
\text { Escherichia sp. } \\
\text { Streptococcus iniae } \\
\text { S. faecalis } \\
\text { S. agalactiae }\end{array}$ & $\begin{array}{r}5.0 \\
5.0 \\
2.5 \\
7.5 \\
7.5 \\
2.5 \\
2.5 \\
2.5 \\
10.0 \\
\end{array}$ \\
\hline $\begin{array}{l}\text { Gadjah Mungkur } 3 \\
\text { (Kedungjati 1) }\end{array}$ & 5.760 & 6 & $\begin{array}{l}\text { Aeromonas hydrophila } \\
\text { Psudomonas sp. } \\
\text { Cytrobactetr sp. } \\
\text { Enterobacter sp. } \\
\text { Alteromonas } \\
\text { Acinetobacter sp. } \\
\text { Esherichia sp. } \\
\text { S. faecalis } \\
\text { S. agalactae }\end{array}$ & $\begin{array}{l}2.5 \\
7.5 \\
7.5 \\
5.0 \\
2.5 \\
2.5 \\
2.5 \\
5.0 \\
2.5\end{array}$ \\
\hline $\begin{array}{l}\text { Gadjah Mungkur } 4 \\
\text { (Kedungjati 2) }\end{array}$ & 6.300 & 6 & $\begin{array}{l}\text { Aeromonas hydrophila } \\
\text { Cytrobacter } \mathrm{sp} \text {. } \\
\text { S. faecalis }\end{array}$ & $\begin{array}{r}10.0 \\
12.5 \\
2.5 \\
\end{array}$ \\
\hline
\end{tabular}


Tabel 3. Kisaran kualitas air di Waduk Cirata dan Gadjah Mungkur pada musim penghujan dan musim kemarau

Table 3. Range of water qualities at Cirata and Gadjah Mungkur reservoirs in rainy and dry seasons

\begin{tabular}{|c|c|c|c|c|}
\hline \multirow{3}{*}{$\begin{array}{l}\text { Parameter } \\
\text { Parameter }\end{array}$} & \multicolumn{4}{|c|}{$\begin{array}{l}\text { Kisaran kualitas air di } \\
\text { Range of water quality in }\end{array}$} \\
\hline & \multicolumn{2}{|c|}{$\begin{array}{l}\text { Waduk Cirata pada musim } \\
\text { Cirata reservoirs in season }\end{array}$} & \multicolumn{2}{|c|}{$\begin{array}{l}\text { Waduk Gadjah Mungkur musim } \\
\text { Gadjah mungkur reservoirs in season }\end{array}$} \\
\hline & Hujan (Rainy) & Kemarau (Dry) & Hujan (Rainy) & Kemarau (Dry) \\
\hline $\begin{array}{l}\text { Oksigen terlarut } \\
\text { Disolved oxygen (mg/L) }\end{array}$ & $2.2--7.4$ & $5.2--6.6$ & $5.5--7.4$ & $7.1--9.4$ \\
\hline $\begin{array}{l}\text { Karbondioksida } \\
\text { Carbon dioxide (mg/L) }\end{array}$ & $4.4--12.1$ & $2.6--14.6$ & $2.6--5.8$ & $1.3--3.0$ \\
\hline $\begin{array}{l}\text { Temperatur air } \\
\text { Water temperature }\left({ }^{\circ} \mathrm{C}\right)\end{array}$ & $28.1--30.0$ & $29.0--29.8$ & $29.0--30.0$ & $26.0--27.5$ \\
\hline $\mathrm{pH}$ & $7.00--7.50$ & 7.5 & $7.00--8.00$ & $8.3--8.6$ \\
\hline Alkalinitas (Alcalinity) (mg/L) & $75.5--92.5$ & $73.1--107.1$ & $179.2--219.8$ & $103.0--112.8$ \\
\hline Hardness (mg/L) & $53.3--69.2$ & $86.4--98.1$ & 74.6--90.6 & $85.2--109.0$ \\
\hline Kalsium (Calcium ) (mg/L) & $26.6--49.0$ & $29.8--46.9$ & $41.3--50.6$ & $48.8--55.1$ \\
\hline Magnesium (mg/L) & $17.0--22.4$ & $39.9--50.3$ & $25.8--33.7$ & $26.4--46.4$ \\
\hline Amonia (mg/L) & $0.012--0.056$ & $0.026--0.039$ & $0.035--0.044$ & $0.046--0.061$ \\
\hline Nitrit (Nitrite) (mg/L) & $0.10--0.22$ & $0.269--0.293$ & $0.020--0.181$ & $0.136--0.184$ \\
\hline Nitrat (Nitrate) (mg/L) & $0.022--0.037$ & $0.031--0.034$ & $0.018--0.041$ & $0.027--0.083$ \\
\hline Fosfat (Phosphate) (mg/L) . & $0.07--0.16$ & $0.067--0.085$ & $0.051--0.083$ & $0.157--0.298$ \\
\hline Organic mater (mg/L) & $9.42--14.28$ & $8.07--18.63$ & $6.42--9.63$ & $8.78--28.87$ \\
\hline $\mathrm{BOD}(\mathrm{mg} / \mathrm{L})$ & $2.51--5.73$ & $2.69--5.66$ & $2.94--3.70$ & $2.21--4.69$ \\
\hline TS (mg/L) & $112.0--215.3$ & $153.3--248.0$ & $134.6--167.3$ & $77.3--119.0$ \\
\hline TSS (mg/L) & 24.0--61.3 & 12.6--20.0 & $37.6--56.6$ & $60.3--68.3$ \\
\hline $\mathrm{Pb}(\mathrm{mg} / \mathrm{L})$ & nd & $0.000--0.017$ & $0.003--0.012$ & $0.013--0.056$ \\
\hline $\mathrm{Cd}(\mathrm{mg} / \mathrm{L})$ & nd & 0 & 0.001 & $0.000--0.001$ \\
\hline $\mathrm{Cr}(\mathrm{mg} / \mathrm{L})$ & nd & $0.035--0.047$ & $0.018--0.023$ & $0.043--0.216$ \\
\hline $\mathrm{Cu}(\mathrm{mg} / \mathrm{L})$ & nd & $0.000--0.003$ & $0.004--0.013$ & 0.004 \\
\hline $\mathrm{Zn}(\mathrm{mg} / \mathrm{L})$ & nd & $0.000--0.003$ & $0.007--0.043$ & $0.004--0.009$ \\
\hline
\end{tabular}

menimbulkan masalah pada ikan dalam waktu dedah yang lama adalah 0,01-0,02 $\mathrm{mg} / \mathrm{L}$, sedangkan level batas terendah yang toksik bagi ikan adalah 0,2$0,5 \mathrm{mg} / \mathrm{L}$. Di lokasi lain Cirata 3 (Lampiran 1) ternyata baik amonia maupun kandungan bahan organiknya cukup rendah yaitu masing-masing $0,012 \mathrm{mg} / \mathrm{L}$ dan $9,42 \mathrm{mg} / \mathrm{L}$. Demikian juga dengan kandungan bahan terlarut (TSS) ternyata di lokasi Cirata 3 lebih rendah apabila dibandingkan dengan lokasi lainnya.

Jumlah dan jenis bakteri kelihatannya meningkat pada musim kemarau baik di Waduk Cirata maupun Waduk Gadjah Mungkur. Hal ini ada kaitannya dengan kualitas air di mana pada musim kemarau terjadi penurunan kualitas. Perubahan kualitas air tersebut dengan jelas terlihat misalnya pada kesadahan, kandungan amonia, dan kandungan bahan organik terutama di Waduk Gadjah Mungkur, terjadi peningkatan.
Dengan keadaan demikian maka bakteri akan berkembang dengan pesat dan jumlah spesiesnya pun bertambah. Dengan terjadinya perubahan kualitas air maka terjadi penekanan-penekanan bagi ikan sehingga ikan menderita stres dan akhirnya akan mudah terinfeksi oleh penyakit yang dalam hal ini adalah penyakit bakterial.

Tingkat keasaman air $(\mathrm{pH})$ di kedua waduk pada waktu $m$ im penghujan ternyata tetap normal berkisar antara 7-8. Namun pada musim kemarau terjadi peningkatan $\mathrm{pH}$ terutama di Waduk Gadjah Mungkur menuju ke arah alkalin dengan kisaran antara 8,38,6 (Tabel 4). Pada keadaan demikian biasanya akan terjadi peningkatan pertumbuhan bakteri. Seperti dikatakan oleh Boyd (1979), bahwa pertumbuhan bakteri akan lebih baik pada keadaan pH normal sampai relatif alkalin (basa). Hal ini terjadi di Waduk Gadjah Mungkur yaitu jumlah bakteri bertambah pada 
musim kemarau karena selain faktor perubahan $\mathrm{pH}$ juga dipacu oleh perubahan unsur lain seperti peningkatan kandungan amonia dan juga kandungan bahan organik.

Kandungan logam berat yang dipantau seperti: $\mathrm{Pb}$, $\mathrm{Cd}, \mathrm{Cr}, \mathrm{Cu}$, dan $\mathrm{Zn}$ di Waduk Cirata baik pada musim penghujan maupun musim kemarau, serta di Waduk Gadjah Mungkur pada musim penghujan, ternyata masih dalam batas yang direkomendasikan. Sedangkan kandungan bahan logam berat $\mathrm{Cr}$ di Waduk Gadjah Mungkur pada musim kemarau ternyata meningkat melebihi batas nilai yang direkomendasikan yaitu mencapai kisaran 0,086 sampai 0,2 mg/L (Lampiran 4), sedangkan batas yang direkomendasikan sesuai yang dikemukakan oleh Darmono (2001) adalah 0,05 mg/L.

\section{KESIMPULAN}

- Jumlah dan jenis penyakit bakterial pada ikan nila di dua waduk, secara deskriptif berbeda antara musim penghujan dan musim kemarau.

- Jumlah dan jenis bakteri patogen pada musim kemarau lebih bervariasi dari pada musim penghujan.

\section{UCAPAN TERIMA KASIH}

Penulis mengucapkan terima kasih kepada Kepala Dinas Perikanan Kabupaten Wonogiri yang telah banyak membantu penelitian ini. Terima kasih juga kami sampaikan kepada Aqua Farm dan BapakBapak petani ikan di Cirata dan Gadjah Mungkur yang telah membantu menyediakan sampel.

\section{DAFTAR PUSTAKA}

Amos, K.H. (Ed.). 1985. Procedures for the detection and identification of certain fish pathogen. $3^{\text {rd }}$ ed. Fish
Health Section, American Fisheries Society. Corvallis, Oregon, $114 \mathrm{pp}$.

Andrews, C., A. Exell, and N. Carrington. 1988. The Interpet Manual of Fish Health. Salamander Books Ltd London, 208 pp.

Boyd, C. 1979. Water Quality in Warmwater Fish Ponds. Auburn University Agricultural Experiment Station, 359 pp.

Cowan, S.T. 1985. Manual for the Identification of Medical Bacteria. Cambridge University Press. Cambridge, $238 \mathrm{pp}$.

Darmono. 2001. Lingkungan Hidup dan Pencemaran. Hubungannya dengan Toksikologi Senyawa Logam. Universitas Indonesia, 179 pp.

Frerichs, G.N. and S.D. Millar. 1993. Manual for The Isolation and Identification of Fish Bacterial Pathogens. Pisces Press, Stirling, 58 pp.

Perera, R.P., S.K. Johnson, M.D. Collins, and D.H. Lewis 1994. Streptococcus iniae Associated with Mortality of Tilapia nilotica x T. aurea Hybrids. J. Aquatic Animal Health, 6: 335-340

Supriyadi, H. dan P. Taufik. 1981. Identifikasi dan cara penanggulangan penyakit bakterial pada ikan lele (Clarias batrachus). Bull. Perik. I, (3): 447-454.

Supriyadi, H. dan A. Rukyani. 1990. Immunopropilaksis dengan cara vaksinasi pada usaha budi daya ikan. Seminar Nasional Ke II, Penyakit Ikan dan Udang, Bogor. 16-18 Januari 1990, 7 pp.

Supriyadi, H. 1992. Identifikasi dan Cara Penanggulangan Pernyakit Bakterial pada Ikan Nila. Dalam Hambali Supriyadi et al. (Eds.). Pros. Seminar Hasil Pen. Perik. Air Tawar 1991/1992 Cipayung 2022 Oktober 1992. Balai Penelitian Perikanan Air Tawar, Bogor, p. 59-63.

Taufik, P. 1992. Penyakit pada ikan gurame (Osphronemus gouramy Lac.) dan penanggulangannya. Makalah pada Pertemuan Aplikasi Teknologi Budidaya Ikan Gurame, 24-26 Agustus 1992 di Yogyakarta, 6 pp. 
Lampiran 1. Kualitas air pada empat lokasi di Waduk Cirata pada musim penghujan

Appendix 1. Water quality of four locations at Cirata reservoir during rainy season

\begin{tabular}{|c|c|c|c|c|}
\hline \multirow{2}{*}{$\begin{array}{l}\text { Parameter } \\
\text { Parameter }\end{array}$} & \multicolumn{4}{|c|}{$\begin{array}{l}\text { Nilai kualitas parameter pada lokasi } \\
\text { Value of water quality parameter at }\end{array}$} \\
\hline & Cirata 1 & Cirata 2 & Cirata 3 & Cirata 4 \\
\hline Oksigen terlarut (Disolved oxygen) (mg/L) & 6.530 & 6.330 & 7.466 & 2.216 \\
\hline Karbondioksida (Carbon dioxide) (mg/L) & 4.400 & 12.126 & 5.860 & 5.990 \\
\hline Temperatur air (Water temperature) $\left({ }^{\circ} \mathrm{C}\right)$ & 29.000 & 30.000 & 30.000 & 28.166 \\
\hline $\mathrm{pH}$ & 7.500 & 7.000 & 7.500 & 7.000 \\
\hline Alkalinitas (Alcalinity) (mg/L) & 82.800 & 82.810 & 75.516 & 92.510 \\
\hline Hardness (mg/L) & 53.330 & 53.333 & 53.333 & 69.253 \\
\hline Kalsium (Calcium) (mg/L) & 26.660 & 29.333 & 30.666 & 49.000 \\
\hline Magnesium (mg/L) & 22.470 & 20.230 & 19.106 & 17.073 \\
\hline Amonia (mg/L) & 0.016 & 0.016 & 0.012 & 0.056 \\
\hline Nitrit (Nitrite) (mg/L) & 0.101 & 0.110 & 0.110 & 0.224 \\
\hline Nitrat (Nitrate) (mg/L) & 0.026 & 0.022 & 0.028 & 0.037 \\
\hline Fosfat (Phosphate) (mg/L) & 0.074 & 0.084 & 0.165 & 0.080 \\
\hline Bahan organik terlarut (Organic mater) $(\mathrm{mg} / \mathrm{L})$ & 14.700 & 12.770 & 9.423 & 14.286 \\
\hline $\mathrm{BOD}(\mathrm{mg} / \mathrm{L})$ & 5.730 & 4.666 & 5.333 & 2.516 \\
\hline $\mathrm{TS}(\mathrm{mg} / \mathrm{L})$ & 182.660 & 215.333 & 112.000 & 143.333 \\
\hline TSS & 52.000 & 61.333 & 24.000 & 33.666 \\
\hline
\end{tabular}


Lampiran 2. Kualitas air pada empat lokasi di Waduk Gadjah Mungkur pada musim penghujan Appendix 2. Water quality of four locations at Gadjah Mungkur reservoir during rainy season

\begin{tabular}{|c|c|c|c|c|}
\hline \multirow{2}{*}{$\begin{array}{l}\text { Parameter } \\
\text { Parameter }\end{array}$} & \multicolumn{4}{|c|}{$\begin{array}{l}\text { Nilai kualitas parameter pada lokasi } \\
\text { Value of water quality parameter at- }\end{array}$} \\
\hline & GM 1 & GM 2 & GM 3 & GM 4 \\
\hline Oksigen terlarut (Disolved oxygen) (mg/L) & 4.893 & 5.533 & 7.463 & 7.216 \\
\hline Karbondioksida (Carbon dioxide) (mg/L) & 5.856 & 3.856 & 2.651 & 2.523 \\
\hline Temperatur air (Water temperature $)\left({ }^{\circ} \mathrm{C}\right)$ & 29 & 29.000 & 29.000 & 30.000 \\
\hline $\mathrm{pH}$ & 7 & 7.500 & 8.000 & 8.000 \\
\hline Alkalinitas (Alcalinity) (mg/L) & 215.303 & 179.170 & 213.800 & 219.823 \\
\hline Hardness (mg/L) & 77.333 & 74.666 & 81.333 & 90.666 \\
\hline Kalsium (Calcium) (mg/L) & 41.333 & 44.000 & 50.666 & 50.666 \\
\hline Magnesium (mg/L) & 29.296 & 25.850 & 25.853 & 33.720 \\
\hline Amonia (mg/L) & 0.035 & 0.044 & 0.043 & 0.044 \\
\hline Nitrit (Nitrite) (mg/L) & 0.02 & 0.181 & 0.039 & 0.156 \\
\hline Nitrat (Nitrate) $(\mathrm{mg} / \mathrm{L})$ & 0.018 & 0.019 & 0.041 & 0.041 \\
\hline Fosfat (Phosphate) (mg/L) & 0.054 & 0.051 & 0.083 & 0.063 \\
\hline Bahan organik terlarut (Organic mater) $(\mathrm{mg} / \mathrm{L})$ & 6.603 & 6.420 & 8.180 & 9.630 \\
\hline BOD $(\mathrm{mg} / \mathrm{L})$ & 3.703 & 2.350 & 2.943 & 3.056 \\
\hline $\mathrm{TS}(\mathrm{mg} / \mathrm{L})$ & 156.666 & 134.666 & 160.666 & 167.333 \\
\hline TSS (mg/L) & 37.666 & 43.333 & 54.666 & 56.666 \\
\hline $\mathrm{Pb}(\mathrm{mg} / \mathrm{L})$ & 0.012 & 0.003 & 0.006 & 0.003 \\
\hline $\mathrm{Cd}(\mathrm{mg} / \mathrm{L})$ & 0.001 & 0.001 & 0.001 & 0.001 \\
\hline $\mathrm{Cr}(\mathrm{mg} / \mathrm{L})$ & 0.022 & 0.023 & 0.022 & 0.018 \\
\hline $\mathrm{Cu}(\mathrm{mg} / \mathrm{L})$ & 0.008 & 0.013 & 0.011 & 0.004 \\
\hline $\mathrm{Zn}(\mathrm{mg} / \mathrm{L})$ & 0.043 & 0.037 & 0.007 & 0.007 \\
\hline
\end{tabular}


Lampiran 3. Kualitas air pada empat lokasi di Waduk Cirata pada musim kemarau

Appendix 3. Water quality of four locations at Cirata reservoir during dry season

\begin{tabular}{|c|c|c|c|c|}
\hline \multirow{2}{*}{$\begin{array}{l}\text { Parameter } \\
\text { Parameter }\end{array}$} & \multicolumn{4}{|c|}{$\begin{array}{l}\text { Nilai kualitas parameter pada lokasi } \\
\text { Value of water quality parameter at- }\end{array}$} \\
\hline & Cirata 1 & Cirata 2 & Cirata 3 & Cirata 4 \\
\hline Oksigen terlarut (Disolved oxygen) (mg/L) & 6.646 & 5.273 & 5.520 & 5.273 \\
\hline Karbondioksida (Carbon dioxide) (mg/L) & 8.656 & 7.970 & 2.666 & 14.646 \\
\hline Temperatur air (Water temperature) $\left({ }^{\circ} \mathrm{C}\right.$ ) & 29.166 & 29.000 & 29.000 & 29.833 \\
\hline $\mathrm{pH}$ & 7.500 & 7.500 & 7.500 & 7.500 \\
\hline Alkalinitas (A/calinity) (mg/L) & 95.756 & 104.683 & 73.123 & 107.120 \\
\hline Hardness (mg/L) & 86.400 & 89.600 & 88.000 & 98.133 \\
\hline Kalsium (Calcium) (mg/L) & 33.066 & 29.866 & 40.533 & 46.933 \\
\hline Magnesium (mg/L) & 44.960 & 50.353 & 39.983 & 43.150 \\
\hline Amonia $(\mathrm{mg} / \mathrm{L})$ & 0.038 & 0.029 & 0.026 & 0.039 \\
\hline Nitrit (Nitrite) (mg/L) & 0.293 & 0.290 & 0.269 & 0.275 \\
\hline Nitrat (Nitrate) (mg/L) & 0.032 & 0.034 & 0.031 & 0.031 \\
\hline Fosfat (Phosphate) (mg/L) & 0.085 & 0.070 & 0.067 & 0.075 \\
\hline Bahan organik terlarut (Organic mater) (mg/L) & 18.633 & 8.076 & 17.713 & 14.596 \\
\hline $\mathrm{BOD}(\mathrm{mg} / \mathrm{L})$ & 5.663 & 2.816 & 2.696 & 3.430 \\
\hline TS (mg/L) & 248.000 & 168.000 & 180.666 & 153.333 \\
\hline TSS (mg/L) & 15.666 & 12.666 & 20.000 & 10.333 \\
\hline $\mathrm{Pb} \cdot(\mathrm{mg} / \mathrm{L})$ & 0.000 & 0.001 & 0.017 & 0.017 \\
\hline $\mathrm{Cd}(\mathrm{mg} / \mathrm{L})$ & 0.000 & 0.000 & 0.000 & 0.000 \\
\hline $\mathrm{Cr}(\mathrm{mg} / \mathrm{L})$ & 0.047 & 0.047 & 0,047 & 0.035 \\
\hline $\mathrm{Cu}(\mathrm{mg} / \mathrm{L})$ & 0.000 & 0.000 & 0.000 & 0.003 \\
\hline $\mathrm{Zn}(\mathrm{mg} / \mathrm{L})$ & 0.001 & 0.000 & 0.002 & 0.003 \\
\hline
\end{tabular}


Lampiran 4. Kualitas air pada empat lokasi di Waduk Gadjah Mungkur pada musim kemarau Appendix 4. Water quality of four locations at Gadjah Mungkur reservoir during dry season

\begin{tabular}{|c|c|c|c|c|}
\hline \multirow{2}{*}{$\begin{array}{l}\text { Parameter } \\
\text { Parameter }\end{array}$} & \multicolumn{4}{|c|}{$\begin{array}{l}\text { Nilai kualitas parameter pada lokasi } \\
\text { Value of water quality parameter at }\end{array}$} \\
\hline & GM 1 & GM 2 & GM 3 & GM 4 \\
\hline Oksigen terlarut (Disolved oxygen) (mg/L) & 7.116 & 8.866 & 7.116 & 9.473 \\
\hline Karbondioksida (Carbon dioxide) (mg/L) & 3.056 & 1.456 & 1.326 & 1.426 \\
\hline Temperatur air (Water temperature) $\left({ }^{\circ} \mathrm{C}\right)$ & 26.000 & 26.000 & 26.000 & 27.500 \\
\hline $\mathrm{pH}$ & 8.500 & 8.500 & 8.666 & 8.333 \\
\hline Alkalinitas (Alcalinity) (mg/L) & 103.060 & 112.796 & 109.553 & 111.986 \\
\hline Hardness (mg/L) & 109.040 & 104.026 & 92.746 & 85.226 \\
\hline Kalsium (Calcium) (mg/L) & 55.146 & 48.880 & 52.640 & 53.893 \\
\hline Magnesium (mg/L) & 45.436 & 46.490 & 33.813 & 26.416 \\
\hline Amonia $(\mathrm{mg} / \mathrm{L})$ & 0.053 & 0.047 & 0.046 & 0.061 \\
\hline Nitrit (Nitrite) (mg/L) & 0.141 & 0.143 & 0.136 & 0.184 \\
\hline Nitrat (Nitrate) (mg/L) & 0.028 & 0.027 & 0.083 & 0.083 \\
\hline Fosfat (Phosphate) (mg/L) & 0.157 & 0.214 & 0.294 & 0.298 \\
\hline Bahan organik terlarut (Organic mater) $(\mathrm{mg} / \mathrm{L})$ & 28.876 & 8.780 & 13.150 & 19.256 \\
\hline $\mathrm{BOD}(\mathrm{mg} / \mathrm{L})$ & 4.543 & 3.590 & 2.213 & 4.690 \\
\hline $\mathrm{TS}(\mathrm{mg} / \mathrm{L})$ & 106.000 & 77.333 & 119.000 & 119.000 \\
\hline TSS (mg/L) & 66.000 & 64.333 & 68.333 & 60.333 \\
\hline $\mathrm{Pb}(\mathrm{mg} / \mathrm{L})$ & 0.020 & 0.013 & 0.021 & 0.056 \\
\hline $\mathrm{Cd}(\mathrm{mg} / \mathrm{L})$ & 0.001 & 0.000 & 0.001 & 0.000 \\
\hline $\mathrm{Cr}(\mathrm{mg} / \mathrm{L})$ & 0.095 & 0.086 & 0.216 & 0.043 \\
\hline $\mathrm{Cu}(\mathrm{mg} / \mathrm{L})$ & 0.004 & 0.004 & 0.004 & 0.004 \\
\hline $\mathrm{Zn}(\mathrm{mg} / \mathrm{L})$ & 0.009 & 0.007 & 0.006 & 0.004 \\
\hline
\end{tabular}


